\title{
Obtaining more benefits from crop residues as soil amendments by application as chemically heterogeneous mixtures
}

\author{
Marijke Struijk $^{1,2}$, Andrew P. Whitmore ${ }^{2}$, Simon R. Mortimer ${ }^{3}$, and Tom Sizmur ${ }^{1}$ \\ ${ }^{1}$ Department of Geography and Environmental Science, University of Reading, Reading, UK \\ ${ }^{2}$ Department of Sustainable Agriculture Sciences, Rothamsted Research, Harpenden, UK \\ ${ }^{3}$ School of Agriculture, Policy and Development, University of Reading, Reading, UK \\ Correspondence: Marijke Struijk (m.struijk@pgr.reading.ac.uk, mstruijk@gmx.com)
}

Received: 19 February 2020 - Discussion started: 27 March 2020

Revised: 1 July 2020 - Accepted: 18 July 2020 - Published: 7 October 2020

\begin{abstract}
Crop residues are valuable soil amendments in terms of the carbon and other nutrients they contain, but the incorporation of residues does not always translate into increases in nutrient availability, soil organic matter (SOM), soil structure, and overall soil fertility. Studies have demonstrated accelerated decomposition rates of chemically heterogeneous litter mixtures, compared to the decomposition of individual litters, in forest and grassland systems. Mixing high $\mathrm{C}: \mathrm{N}$ ratio with low $\mathrm{C}: \mathrm{N}$ ratio amendments may result in greater carbon use efficiency (CUE) and nonadditive benefits in soil properties.

We hypothesised that nonadditive benefits would accrue from mixtures of low-quality (straw or woodchips) and high-quality (vegetable waste compost) residues applied before lettuce planting in a full factorial field experiment. Properties indicative of soil structure and nutrient cycling were used to assess the benefits from residue mixtures, including soil respiration, aggregate stability, bulk density, SOM, available N, potentially mineralisable $\mathrm{N}$, available $\mathrm{P}, \mathrm{K}$, and $\mathrm{Mg}$, and crop yield.

Soil organic matter and mineral $\mathrm{N}$ levels were significantly and nonadditively greater in the straw-compost mixture compared to individual residues, which mitigated the $\mathrm{N}$ immobilisation occurring with straw-only applications. The addition of compost significantly increased available $\mathrm{N}, \mathrm{K}$, and $\mathrm{Mg}$ levels. Together, these observations suggest that greater nutrient availability improved the ability of decomposer organisms to degrade straw in the straw-compost mixture.

We demonstrate that mixtures of crop residues can influence soil properties nonadditively. Thus, greater benefits may be achieved by removing, mixing, and reapplying crop residues than by simply returning them to the soils in situ.
\end{abstract}

\section{Introduction}

Intensive agricultural systems, with a monoculture of crops and relying on external inputs of fertilisers, pesticides and/or herbicides, are criticised for their negative environmental impacts. These include the degradation of soil - particularly the degradation of soil organic matter (SOM), biodiversity loss, and the overapplication of $\mathrm{N}$ and $\mathrm{P}$ (Malézieux et al., 2009; Tilman et al., 2002). Implementing multispecies cropping systems (e.g. Malézieux et al., 2009) and increasing functional diversity via trait-based approaches (Garnier and Navas, 2012) are some methods that have been proposed to increase biodiversity and functional complementarity of the variety of species present in arable cropping systems. These approaches can lead to more sustainable nutrient cycling, reduced soil erosion, stabilised crop production, and improvements to a system's innate capacity to resist pests, diseases, and other environmental disturbances (Gurr et al., 2003). However, some farming systems prevent the cultivation of more than one crop in a field at any one time, and so 
applying mixtures of crop residues may provide an alternative route to obtaining the benefits of multispecies cropping within monocultural arable cropping systems.

Crop residues comprise the majority of plant materials harvested worldwide (Medina et al., 2015; Smil, 1999) and are readily available on arable farms. Containing carbon and other nutrients, they present a valuable resource as soil amendments with the potential to increase SOM and nutrient levels, which feed the soil food web (Kumar and Goh, 1999) and may increase soil aggregation and improve soil structure (Cosentino et al., 2006; Martin et al., 1955). Unfortunately, while these changes in soil properties are likely to lead to increased crop yield, the decomposition of residue soil amendments does not always translate into such benefits and is instead followed by losses from the system, with lower soil $\mathrm{N}$ retention and C levels than expected (Catt et al., 1998; Powlson et al., 2011; Thomsen and Christensen, 2006).

Rather than applying a single crop residue, mixtures of crop residues could form a better soil amendment. Complementarity in mixtures of different residues has previously been shown in research on the decomposition rates of mixtures of moss and leaf litters in forest ecosystems and grass clippings in grassland ecosystems (Gartner and Cardon, 2004; Hättenschwiler et al., 2005). Synergistic nonadditive mixing effects are frequently observed, i.e. decomposition of the mixture is greater than would be predicted from the rate of decomposition of individual litter types, especially when the litters are chemically heterogeneous (Pérez Harguindeguy et al., 2008; Wardle et al., 1997).

Suggested mechanisms for nonadditive decomposition rates of mixtures include physical, chemical, and biological processes (Gartner and Cardon, 2004). Frequently cited is the mechanism that $\mathrm{N}$-rich residues are thought to accelerate the decomposition of N-poor residues (Seastedt, 1984) by the interspecific transfer of nutrients in the residue mixture (Berglund et al., 2013; Briones and Ineson, 1996). Additionally, more heterogeneous and improved microenvironmental conditions increase habitat and resource options for decomposer organisms (Hättenschwiler et al., 2005), also known as the improved microenvironmental condition theory (Makkonen et al., 2013).

However, whether synergistic decomposition rates in mixtures are related to benefits in terms of soil nutrient and carbon management is unclear because studies on the $\mathrm{C}$ and $\mathrm{N}$ dynamics in decomposing residue mixtures are limited (Redin et al., 2014). It has been shown that increased plant species richness can promote soil $\mathrm{C}$ and $\mathrm{N}$ stocks via higher plant productivity (Cong et al., 2014) and lead to increased diversity and functionality of soil microbes (Lange et al., 2015) as well as the whole soil food web (Eisenhauer et al., 2013). Quemada and Cabrera (1995) found nonadditivity in the $\mathrm{C}$ and $\mathrm{N}$ dynamics when mixtures of leaves and stems were decomposed, compared to individual residues, with the $\mathrm{C}: \mathrm{N}$ ratio of the residues playing an important role in $\mathrm{N}$ mineralisation. Nilsson et al. (2008) reported synergistic effects on available $\mathrm{N}$ and on plant productivity when mixing Populus tremula litter $(\mathrm{C}: \mathrm{N}=40$; known to decompose quickly) with Empetrum hermaphroditum (C: $\mathrm{N}=77$; known to decompose slowly). These experiments suggest that nonadditivity in decomposition rates and changes to soil $\mathrm{C}$ and soil $\mathrm{N}$ dynamics could go hand in hand.

Increasingly more evidence is emerging that SOM accumulation is primarily derived from the production of microbial residues (Ludwig et al., 2015; Simpson et al., 2007), and this microbially derived SOM seems to be produced in the early stages of plant residue decomposition (Cotrufo et al., 2015). Microbial carbon use efficiency (CUE) describes a functional trait of microbes that refers to the fraction of carbon assimilated from organic matter additions to the soil system compared to $\mathrm{C}$ losses to the atmosphere via microbial respiration (Allison et al., 2010). Different microbial species exhibit an inherent CUE window so that they can operate at different CUE levels to fulfil their maintenance and growth $C$ requirements, depending on environmental factors (Schimel et al., 2007). Organic substrates can feed into different microbial metabolic pathways (e.g. anabolism versus catabolism) or microbial communities that exhibit different overall inherent CUE levels (e.g. fungi versus bacteria or copiotrophs versus oligotrophs; Jones et al., 2018). Therefore, an increase in the amount of SOM from microbial activity is not linearly related to $\mathrm{CO}_{2}$ production, or to the quantity of $\mathrm{C}$ applied to the soil, but depends also on the CUE of the decomposer community.

Fertilisation practices typical of intensively managed arable soils stimulate copiotrophic microorganisms (Fierer et al., 2012) with boom-bust population dynamics. These microbial communities tend to exhibit a lower inherent CUE window than slower growing oligotrophic communities (Ho et al., 2017; Roller and Schmidt, 2015). In intensively managed arable soils, the decomposition of soil-applied crop residues can lead to a large portion of residue-derived $\mathrm{C}$ being respired as $\mathrm{CO}_{2}$ rather than turned into SOM (Bailey et al., 2002; Six et al., 2006). Decomposition of high $\mathrm{C}: \mathrm{N}$ residues requires microbes with a relatively high CUE, but due to $\mathrm{N}$ limitation, they operate towards the lower end of their CUE window (Kallenbach et al., 2019). Low C : N residues, providing relatively more $\mathrm{N}$, may increase the CUE of individual microbes but can also shift the composition of the soil microbial community to one that exhibits an inherently lower CUE (Kallenbach et al., 2019). As suggested by Kallenbach et al. (2019), a mixture of crop residues of different $\mathrm{C}: \mathrm{N}$ ratios could therefore achieve a more diverse microbial community, comprising organisms fulfilling niches of both high and low inherent CUE windows, and may enable all species to operate at their maximum CUE. Other authors have also suggested the possibility of manipulating the functionality of the soil microbial community with soil amendments such as Li et al. (2019), who report that microbes in a eutrophic system are stimulated by organic carbon amendments, and oligotrophic microbes are stimulated by chemi- 
cal fertilisers. Studies have also demonstrated that changes in tree litter diversity affect both fungal and bacterial diversity (Otsing et al., 2018; Santonja et al., 2018). Research on decomposition in forest systems indicates a succession in the community composition of microbial decomposers as the decomposition of residues progresses (Bastian et al., 2009; $\mathrm{Pu}-$ rahong et al., 2016), and this succession is different in the decomposition of litters of different qualities (Aneja et al., 2006).

Low-quality plant materials with high $\mathrm{C}: \mathrm{N}$ ratios constitute the majority of crop residues produced by arable farming practices worldwide, typically involving cultivation of corn, wheat, and rice (Medina et al., 2015). The potential of crop residue soil amendments to deliver benefits to crops would be better exploited if the decomposition processes were manipulated for $\mathrm{C}$ to persist in the soil biomass, necromass, or other forms of (semi-)stabilised SOM, such as in soil aggregates. Generally, soil amendments consisting of one large amount of a single crop residue do not always deliver benefits. We suggest that the nonadditive decomposition rates observed in forest litter mixtures, reinforced by recent insights into the link between CUE and the difference in $\mathrm{C}: \mathrm{N}$ ratio of soil organic co-amendments, can inform strategies to obtain more benefits from crop residues as soil amendments. Mixing these crop residues to create chemically diverse crop residue mixtures with a CUE-optimised $\mathrm{C}: \mathrm{N}$ ratio to generate a greater diversity of functionally complementary microbial niches, and to enable each member of the microbial community to function at a maximised CUE, could be a relatively simple method to obtain more benefits from this precious, but ubiquitous, resource. If this approach can attain higher CUE levels for high $\mathrm{C}: \mathrm{N}$ residues, a considerable increase in net SOM could be realised in arable cropping systems, along with other beneficial changes in soil properties (e.g. nutrient retention), leading to greater soil fertility and, meanwhile, increasing biodiversity in otherwise monocultural arable cropping systems.

The aim of this study was to investigate the potential of chemically heterogeneous mixtures of crop residue amendments to improve soil properties for crop production. A field experiment was set up on an intensive organic arable cropping farm. Amendments of mixtures and individual crop residues were applied as follows: vegetable waste compost was used as low $\mathrm{C}: \mathrm{N}$ (high-quality) residue, and wheat straw and woodchips were used as high $\mathrm{C}: \mathrm{N}$ (low-quality) residues. Properties indicative of soil structure and nutrient cycling were used to assess benefits from residue mixtures compared to individual residues, including lettuce crop yield, soil respiration, soil aggregate stability, soil bulk density, SOM, available and potentially mineralisable $\mathrm{N}$, and available $\mathrm{P}, \mathrm{K}$, and $\mathrm{Mg}$. We predicted higher decomposition rates when mixtures of crop residues were applied, compared to individual residue amendments, leading to nonadditive effects in soil properties that could be beneficial for crop production. In particular, we hypothesised faster decomposition
Table 1. Treatment structure composed of the factors residue and compost.

\begin{tabular}{lll}
\hline $\begin{array}{l}\text { Compost } \rightarrow \\
\text { Residue } \downarrow\end{array}$ & Compost & No compost \\
\hline Straw & Straw-compost & Straw \\
Woodchips & Woodchip-compost & Woodchip \\
None & Compost & Control \\
\hline
\end{tabular}

of residue mixtures to result in a higher soil respiration rate in the short term and the release of greater levels of available nutrients ( $\mathrm{N}, \mathrm{P}, \mathrm{K}$, and $\mathrm{Mg}$ ) and SOM compared to what would be expected by combining the effects of individual residues; this leads to a greater ammonification of residue $\mathrm{N}$ (Xu et al., 2006) and, in turn, leads to a greater increase in $\mathrm{pH}$ (hypothesis 1). An increase in SOM will likely change soil physical properties, which we expected to observe as an increase in soil aggregate stability and a decrease in soil bulk density (hypothesis 2). These changes in soil physicochemical properties were subsequently expected to lead to a higher crop yield (hypothesis 3).

\section{Methodology}

\subsection{Study site and experimental design}

A field experiment was set up in an intensively managed horticultural area of lowland fen on an organic farm near Ely in Cambridgeshire, United Kingdom $\left(52^{\circ} 21^{\prime} \mathrm{N}, 0^{\circ} 17^{\prime} \mathrm{E}\right)$. During the experiment, between 11 June and 26 July 2018, the field site was used for growing gem lettuce crops (Lactuca sativa L. var. longifolia; commercial variety "Xamena") following a year of celery crops in 2017 , conversion to organic in 2016 (grass ley), winter wheat in 2015, and beetroot in 2014. The typical crop rotation followed by the farm is celery followed by beetroot, celery, or onion, followed by lettuce, and then followed by a break crop of perennial ryegrass and white clover or a cereal. The experimental plots were located on clay loam, on a roddon, a dried raised bed formed by the deposition of silt and clay from a watercourse which pushed peat to the sides. The mineral parts of the soils typically do not perform as well as the surrounding organic soils because they require more fertiliser, so we expected that they would respond more quickly to residue amendments.

A total of four replicates of six treatments, within a full factorial randomised complete block design of the factors of compost and residue (see Table 1), were applied to $2 \mathrm{~m} \times 6 \mathrm{~m}$ experimental plots within a $6 \mathrm{~m} \times 48 \mathrm{~m}$ field site consisting of $3 \times 8=24$ plots situated between the tyre tracks of farm machinery. All samples were taken from the inner $2 \mathrm{~m} \times 2 \mathrm{~m}$ of each plot to incorporate a $4 \mathrm{~m}$ long buffer zone between plots along the same strip.

The residue amendment treatments were prepared on 17 May 2018. Application rates of the different amendments 
were $20 \mathrm{tha}^{-1}$ compost (equivalent to $7 \mathrm{tha}^{-1}$ dry matter), $13.3 \mathrm{tha}^{-1}$ woodchips (equivalent to $8.7 \mathrm{tha}^{-1}$ dry matter), and $10 \pm 0.8 \mathrm{tha}^{-1}$ straw (equivalent to $9.2 \pm 0.8 \mathrm{tha}^{-1}$ dry matter; \pm indicates inclusive range of the straw application rate). These are within the range of application rates that are common in intensive arable cropping systems in Europe (Recous et al., 1995; Simon Gardner, personal communication, 2018) and were chosen to obtain similar amounts of dry matter for each residue. These rates were consistently applied in both individual amendment treatments and mixtures, so residue-compost treatments contained twice as much dry matter compared to individual amendments. Applications were spread out evenly over the plots by hand on 12 June 2018 (Fig. 1c), followed by power harrowing to incorporate the residues in the soil profile. Gem lettuce plugs were sown on the following day.

\subsection{Soil and residue characterisation}

Baseline soil samples were collected on 11 June 2018 (before organic amendments were applied). For each plot, soil samples were collected as the combination of five $30 \mathrm{~mm}$ diameter soil cores taken to $20 \mathrm{~cm}$ depth. These 24 composite samples were air-dried, disaggregated with the aid of a mortar and pestle, sieved to $2 \mathrm{~mm}$, and analysed for soil moisture (at $105^{\circ} \mathrm{C}$ overnight), SOM by loss on ignition (LOI; at $500{ }^{\circ} \mathrm{C}$ overnight), $\mathrm{pH}$ (after $2 \mathrm{~h}$ of shaking $2.5 \pm 0.005 \mathrm{~g}$ soil with $25 \mathrm{~mL}$ ultrapure water $\left.\left[>18.2 \Omega \mathrm{cm}^{-1}\right]\right)$, and soil texture by laser granulometry (Malvern Mastersizer 3000). A portion of each soil sample was ball milled and analysed for total C and N (Flash 2000; Thermo Fisher Scientific, Cambridge, UK; calibrated with aspartic acid, $104 \% \mathrm{~N}$ and $100 \%$ $\mathrm{C}$ recovery rates of in-house reference soil material traceable to GBW 07412). There were no significant treatment differences for any of these baseline soil variables tested with a one-way analysis of variance (ANOVA) of treatments or a two-way ANOVA of the factors of residue and compost (see $\mathrm{S} 2$ in the Supplement).

All amendments were provided by the farm and sourced and prepared on site. The compost amendment was composed of the following vegetable residues from the farm: spinach, celery, several lettuce varieties, carrots, leeks, spring onions, onions and shallots, cabbage, bell peppers, beetroots, and mushrooms (Fig. 1a-b). Due to the high water content of these residues, the farm co-composts with straw to provide sufficient dry matter content in the compost mixture. The straw amendment used in the treatments containing straw was winter wheat straw available on site, and the woodchip amendment was from poplar trees commonly grown as a wind break in the local area. Dried and milled residues were analysed for total C and N (Flash 2000, as aforementioned; $109 \%$ recovery rate of both $\mathrm{C}$ and $\mathrm{N}$ of in-house reference rapeseed material, traceable to certified reference material GBW 07412). The total concentrations of P, K, and $\mathrm{Mg}$ were determined by inductively coupled plasma optical
Table 2. Residue characterisation. Numbers in parenthesis represent the standard error of the mean (SEM; $n=3)$.

\begin{tabular}{lrrr}
\hline Nutrient & Compost & Straw & Woodchip \\
\hline $\mathrm{C}(\mathrm{g} / \mathrm{kg})$ & $322.3(0.433)$ & $459.0(1.012)$ & $485.3(1.121)$ \\
$\mathrm{N}(\mathrm{g} / \mathrm{kg})$ & $25.3(0.167)$ & $11.2(0.083)$ & $7.6(0.105)$ \\
$\mathrm{C}: \mathrm{N}$ & $12.7(0.084)$ & $40.9(0.368)$ & $63.6(0.760)$ \\
$\mathrm{P}(\mathrm{g} / \mathrm{kg})$ & $5.5(0.076)$ & $1.0(0.025)$ & $0.9(0.024)$ \\
$\mathrm{K}(\mathrm{g} / \mathrm{kg})$ & $20.6(0.31)$ & $13.1(0.22)$ & $5.1(0.10)$ \\
$\mathrm{Mg}(\mathrm{g} / \mathrm{kg})$ & $4.3(0.014)$ & $0.7(0.015)$ & $1.3(0.040)$ \\
$\mathrm{Mn}(\mathrm{g} / \mathrm{kg})$ & $258(1.68)$ & $41(1.15)$ & $41(1.67)$ \\
$\mathrm{Fe}(\mathrm{g} / \mathrm{kg})$ & $15.0(0.051)$ & $0.5(0.015)$ & $1.0(0.060)$ \\
\hline
\end{tabular}

emission spectroscopy (ICP-OES; Optima 7300 dual view, PerkinElmer Inc.; recovery rates of $99 \%$ for P, $94 \%$ for K, $102 \%$ for $\mathrm{Mg}, 92 \%$ for $\mathrm{Mn}$, and $114 \%$ for $\mathrm{Fe}$ of in-house hay reference material, traceable to certified reference no. NCSDC 73349) analysis of $0.5 \mathrm{~g}$ residues samples digested in $8 \mathrm{~mL}$ of nitric acid (trace metal grade) using a MARS 6 microwave digestion system (Table 2).

The amounts of $\mathrm{C}, \mathrm{N}$, and other nutrients applied in each treatment were calculated based on the chemical characterisation of the residues and their application rates (Table 3).

\subsection{Assessment of yield}

Lettuce crops were planted on 14 June 2018 and harvested from the inner $2 \mathrm{~m} \times 2 \mathrm{~m}$ of each plot on 20 and 21 July 2018 , i.e. $38 \mathrm{~d}$ after residue application and $36 \mathrm{~d}$ after planting. Each lettuce head was harvested whole and weighed to calculate the total biomass produced per treatment. Meanwhile, lettuce crops were qualitatively assessed, which included screening for chlorosis, caterpillar damage, tip burn, and rotting. In some cases, dried-out mushrooms were found on the outer leaves, which was also noted.

\subsection{Assessment of soil biogeochemical properties}

All soil samples were taken from the inner $2 \mathrm{~m} \times 2 \mathrm{~m}$ of each plot on 26 July 2018, i.e. 44 d after residue application. From each plot a $10 \mathrm{~cm}$ deep bulk density core of $9.8 \mathrm{~cm}$ diameter was collected. A series of six $30 \mathrm{~mm}$ diameter soil cores to $20 \mathrm{~cm}$ depth were collected, combined, and homogenised in a zip-lock bag, and used for a suite of analyses. A subsample of the fresh soil was sieved to $2 \mathrm{~mm}$ for analysis of available $\mathrm{N}$ (i.e. sum of $\mathrm{NO}_{3}^{-}$and $\mathrm{NH}_{4}^{+}$) by $1 \mathrm{M} \mathrm{KCl}$ extraction before and after a 4-week incubation at $70 \%$ of the water-holding capacity (WHC). Extracts were filtered through a Whatman no. 2 filter and analysed colorimetrically for $\mathrm{NO}_{3}^{-}$and $\mathrm{NH}_{4}^{+}$ on a Skalar $\mathrm{San}^{++}$continuous flow analyser. Available $\mathrm{N}$ was taken as the sum of the $\mathrm{NO}_{3}^{-}$and $\mathrm{NH}_{4}^{+}$measured in the first extract. Potentially mineralisable $\mathrm{N}$ was calculated as the difference in $\mathrm{NO}_{3}^{-}$and $\mathrm{NH}_{4}^{+}$measured before and after the 4-week incubation period. A subsample of the fresh soil 

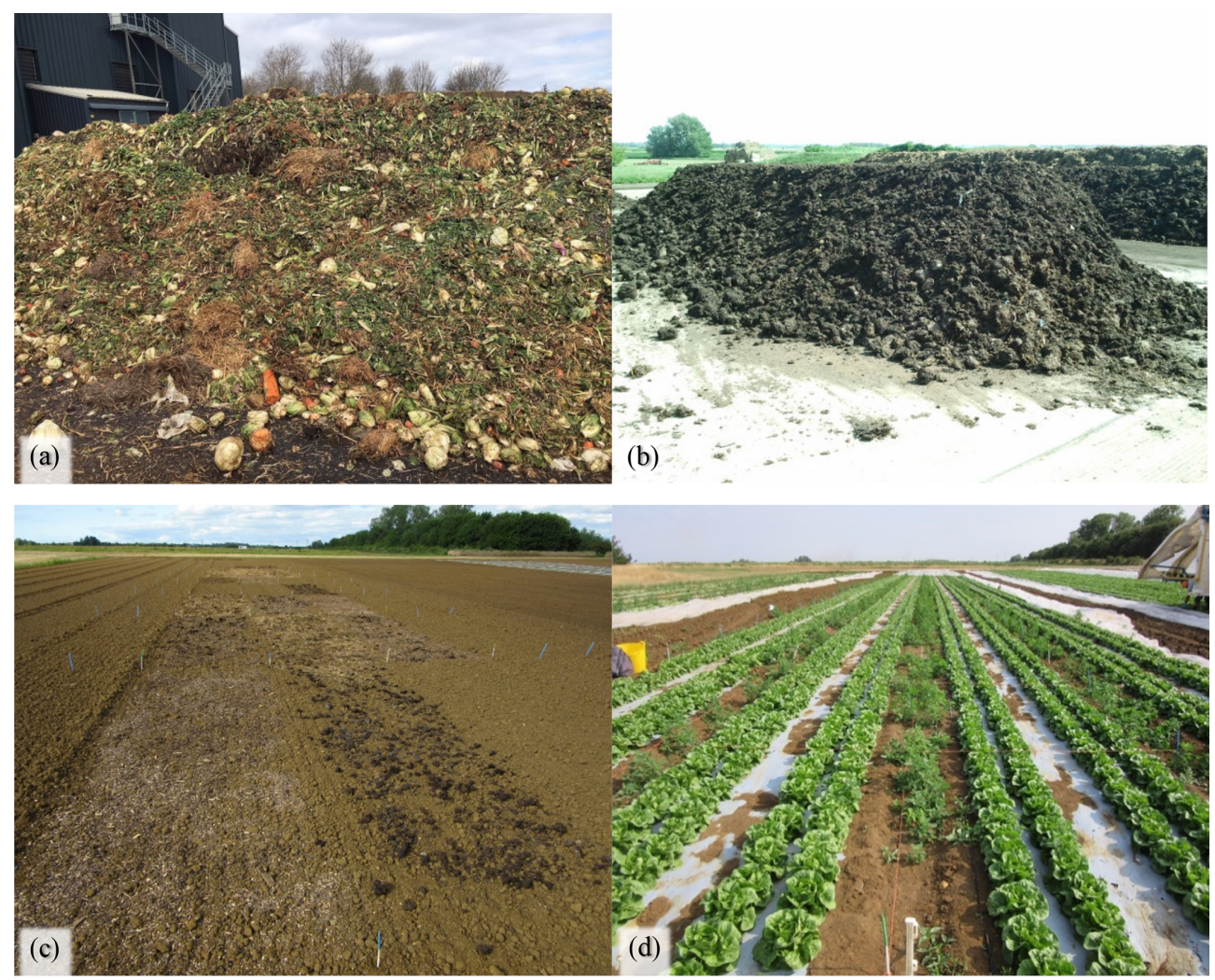

Figure 1. Photographs of the preparation of the mixed compost (a), the final compost product (b), the treatments applied to the experimental plots (c), and the lettuce at the time of harvest (d).

Table 3. Amount (grams per plot) of $\mathrm{C}, \mathrm{N}$ and other nutrients applied in each treatment.

\begin{tabular}{lrrrrr}
\hline & Straw & Woodchip & Compost & Straw-compost & Woodchip-compost \\
\hline $\mathrm{C}$ & 4645 & 5047 & 2707 & 8197 & 7754 \\
$\mathrm{~N}$ & 114 & 79 & 213 & 347 & 292 \\
$\mathrm{C}:$ N ratio & 41 & 64 & 13 & 24 & 27 \\
$\mathrm{P}$ & 11 & 9 & 46 & 59 & 55 \\
$\mathrm{~K}$ & 133 & 53 & 173 & 330 & 226 \\
$\mathrm{Mg}$ & 7 & 14 & 37 & 45 & 50 \\
\hline
\end{tabular}

was sent to NRM laboratories (Cawood Scientific, Bracknell, UK) where it was air-dried and sieved to $2 \mathrm{~mm}$ for measurements of available $\mathrm{P}$ by extraction with $0.5 \mathrm{M} \mathrm{NaHCO}_{3}$, available $\mathrm{K}$ and $\mathrm{Mg}$ by extraction with $1 \mathrm{M} \mathrm{NH}_{4} \mathrm{NO}_{3}$, soil particle size distribution by laser granulometry, SOM based on LOI at $430{ }^{\circ} \mathrm{C}$, and the Solvita $\mathrm{CO}_{2}$ burst test measuring the concentration of $\mathrm{CO}_{2}$ produced by soils moistened to $50 \%$ of their WHC.

Earthworm and mesofauna sampling was performed, but only a few juvenile earthworms were found, which made identification difficult. The endogeic species A. chlorotica was identified in at least three of the 24 plots. The abundance of mesofauna (Collembola and mites) extracted from the soils using Tüllgen funnels was nil. Some Collembola were observed while harvesting the lettuce crop, so their absence from the samples is probably due to the removal of plants that provided some shelter from the hot and dry weather conditions.

Wet aggregate stability was assessed, as per Nimmo and Perkins (2002), using soil samples that were collected into tubs (to prevent soil compression) from the top $10 \mathrm{~cm}$ of each plot and subsequently air-dried. A $4 \mathrm{~g}$ subsample from each plot was slowly pre-wetted on moistened filter paper. The wet-sieving procedure involved a wet-sieving apparatus composed of vertically moving $250 \mu \mathrm{m}$ sieves to hold the soil samples sitting inside a can. The cans were filled up with water, such that the soil was submerged, causing the unstable soil aggregates to break apart and pass through the sieve into 
the can. First, the soils were wet sieved for $3 \mathrm{~min}$ in deionised water to collect unstable soil particles and subsequently in a solution of $2 \mathrm{~g} \mathrm{~L}^{-1}\left(\mathrm{NaPO}_{3}\right)_{6}$ to disperse the water stable aggregates. The stable fraction of soil (i.e. wet aggregate stability) was then calculated as the weight of soil caught by the dispersing solution divided by the sum of the weights of soil caught by both water and dispersant. Any particles larger than $250 \mu \mathrm{m}$ did not pass the sieve and were not included in the calculation.

\subsection{Data analyses}

We observed a gradient in the soil percent of $\mathrm{C}$ and a similar gradient in the percent of the $\mathrm{N}$ content of the baseline soil samples that was not well captured by our original blocking design, so the data were retrospectively blocked accordingly (see S1 in the Supplement). This was necessary because the calculation of nonadditive effects, described below, relies on paired samples within blocks rather than treatment averages across blocks.

Statistical analyses were performed in R Foundation for Statistical Computing 3.5.1, using RStudio 1.1.456 (RStudio, PBC.). To determine the effects of treatments and/or factors on individual soil parameters, a two-way ANOVA, including interactions, with the factors of compost (compost or no compost) and residue (straw, woodchips, or no residue) was performed. If a factor had a significant effect $(p<0.05)$, a post hoc Tukey honestly significant difference (HSD) test was run to determine which treatments were significantly different from each other. Taking into account that four replicates per treatment are a limited number of data points, assumptions of the ANOVA test were assessed both visually and via the relevant statistical tests; homoscedasticity was evaluated with a Q-Q plot of the ANOVA residuals plotted against the fitted data of the ANOVA and a Levene test of the data set. Normal distribution of the residuals was evaluated with a residuals versus fitted plot and a Shapiro-Wilk test of the residuals of the ANOVA. Pearson correlations were performed to investigate relationships between different variables.

Properties indicative of soil structure and nutrient cycling were used to assess the nonadditive effects from residue mixtures compared to individual residues, including lettuce crop yield, soil respiration, soil aggregate stability and bulk density, SOM, available and potentially mineralisable $\mathrm{N}$, and available $\mathrm{P}, \mathrm{K}$, and $\mathrm{Mg}$. The percent effect of each measurement of the treatment effects was first determined by adjusting to the measured effect of the control treatment as follows:

$\%$ effect $=\frac{\text { treatment-control }}{\text { control }} 100 \%$

Next, the percent of the nonadditive effects of the residue mixtures were calculated as the difference between the percent effect of the mixture and the percent effect of the sum of the parts, as follows:

$$
\% \text { non-additive effect } \text { mixture }=\% \text { effect }_{\text {mixture }}
$$$$
-\left(\% \text { effect }_{\text {compost }}+\% \text { effect }_{\text {residue }}\right) \text {, }
$$

where residue refers to straw or woodchips. A one-sided $T$ test of the percent of nonadditive effects was performed with an alternate hypothesis $\left(\mathrm{H}_{1}\right)$ of $\mu>0$ for yield, available $\mathrm{N}$, potentially mineralisable $\mathrm{N}$, available $\mathrm{P}, \mathrm{K}$, and $\mathrm{Mg}$, soil respiration, SOM, aggregate stability, and an alternate hypothesis of $\mu>0$ for bulk density and $\mathrm{pH}$. Normality was tested with a Shapiro-Wilk test.

\section{Results}

\subsection{Nonadditive effects}

Nonadditive effects measured $44 \mathrm{~d}$ after the application of the treatments were mostly synergistic (i.e. mixture $>$ sum of the parts), although the majority of effects were not statistically significant (Fig. 2). The magnitude and direction of the deviation from the additivity were usually similar for both the woodchip-compost and straw-compost mixtures, although nonadditive effects from the woodchip-compost mixture were sometimes less pronounced than those from the straw-compost mixture.

Both compost-residue mixtures resulted in a nonadditive increase in lettuce yield, available and potentially mineralisable $\mathrm{N}$, available $\mathrm{Mg}, \mathrm{SOM}$, and soil respiration but not in available $\mathrm{K}$ (hypothesis 1), some of which was statistically significant as further specified below (Table 4). Most notably, we observed greater available $\mathrm{N}$ and SOM levels in soils to which a mixture of residues was applied compared to the available $\mathrm{N}$ and SOM levels in treatments receiving only individual residue amendments. The straw-compost mixture resulted in a significant $(T=4.022 ; p=0.014)$ nonadditive increase in SOM of $13.10 \%$, and while the woodchipcompost mixture did not result in statistically significant nonadditivity $(T=0.954 ; p=0.205)$, it did result in a positive nonadditive increase in SOM of $6.73 \%$.

Likewise, amendments with the straw-compost mixture led to significantly $(T=3.789 ; p=0.016)$ greater available $\mathrm{N}$ levels that were $55.06 \%$ higher on average than would have been expected from the available $\mathrm{N}$ levels in treatments receiving individual amendments of straw or compost only. The positive nonadditive effect on available $\mathrm{N}$ observed in soils that received the woodchip-compost mixture was, however, smaller $(7.16 \%$ increase on average) and not statistically significant $(T=0.235 ; p=0.415)$. A nonsignificant, nonadditive increase in available $\mathrm{P}$ was only observed after the application of the straw-compost mixture but not after the application of the woodchip-compost mixture (hypothesis 1). In agreement with our hypothesis, there was a nonadditive increase in $\mathrm{pH}$ from the mixtures relative to individual amendments (hypothesis 1), although this was not significant 
Table 4. Statistical outputs of one-tailed $T$ tests of nonadditive effects. Significance of deviation from additivity $(0)$ is indicated as $* * \quad p<0.05$ and ${ }^{*} p<0.1$.

\begin{tabular}{lrrr|rrr}
\hline & \multicolumn{3}{c|}{ Straw-compost mixture } & \multicolumn{3}{|c}{ Woodchip-compost mixture } \\
\cline { 2 - 7 } & $\begin{array}{r}\text { Mean \% } \\
\text { nonadditivity }\end{array}$ & $T$ & $p$ & $\begin{array}{r}\text { Mean \% } \\
\text { nonadditivity }\end{array}$ & $T$ & $p$ \\
\hline Yield & 9.66 & 1.004 & 0.195 & 9.54 & 0.771 & 0.249 \\
Available N & 55.06 & 3.789 & $0.016^{* *}$ & 7.16 & 0.235 & 0.415 \\
Mineralisable N & 39.67 & 1.265 & 0.147 & 8.93 & 0.990 & 0.198 \\
P & 3.01 & 0.226 & 0.417 & -8.60 & -0.788 & 0.756 \\
K & -0.79 & -0.082 & 0.530 & -0.86 & -0.171 & 0.562 \\
Mg & 9.95 & 1.475 & 0.118 & 2.73 & 0.335 & 0.380 \\
SOM & 13.10 & 4.022 & $0.014^{* *}$ & 6.73 & 0.954 & 0.205 \\
pH & 3.04 & 2.006 & 0.931 & 2.41 & 1.118 & 0.828 \\
Respiration & 5.12 & 0.300 & 0.392 & 16.41 & 1.023 & 0.191 \\
Bulk density & -7.80 & -2.232 & $0.056^{*}$ & -3.73 & -0.919 & 0.213 \\
Aggregate stability & 11.41 & 1.555 & 0.109 & 8.57 & 1.291 & 0.144 \\
\hline
\end{tabular}

(Table 4), and per-treatment results (discussed in next section) show that the $\mathrm{pH}$ decreased in all treatments relative to the control $(F=2.238 ; p=0.095$; one-way ANOVA; see $\mathrm{S} 3$ in the Supplement). We also observed nonadditive effects from both compost-residue mixtures on the soil structure, i.e. a decrease in bulk density and an increase in aggregate stability (hypothesis 2), and a nonadditive increase of about $10 \%$ was found for crop yields from both crop residue mixtures (hypothesis 3). Although the effects on soil structure and yield were mostly nonsignificant, the decrease in bulk density after the amendment with the straw-compost mixture was borderline significant $(F=-2.232 ; p=0.056$; Table 4).

The following sections contain the per-treatment results of the soil's physical and biochemical properties measured in this experiment. It should be noted that the application rates of the mixtures were about twice as high as the individual amendments to enable the calculation of nonadditivity, so measurements from residue-mixture treatments cannot be directly compared to individual residue treatments.

\subsection{Per-treatment results}

The yield assessed by the total biomass of gem lettuce produced per plot seemed to be somewhat reduced by the strawonly treatment but was not significantly affected by any of the treatments or factors (Fig. 3a; see S5 in the Supplement for statistical outputs).

Lettuce plants in the straw-only treatments suffered noticeably less damage, particularly from caterpillars, tip burn, and rot (see Table S2 in S3 in the Supplement). There was a significant interaction between the residue and compost factors in terms of the quality of the lettuce plants harvested ( $F=3.568 ; p=0.050$; two-way ANOVA), with the biggest difference being between the straw-only and straw-compost treatments ( $p=0.067$; post hoc Tukey HSD). Mushrooms were observed on the outer leaves of some lettuce heads in plots receiving woodchips and, in two cases, in plots of neighbouring treatments including woodchips, so fungi may have been introduced and/or promoted by the woodchips.

Levels of SOM and N (available and potentially mineralisable) were negatively affected by the straw-only treatment, while treatments of woodchip only and compost only had little effect on SOM and $\mathrm{N}$ levels compared to the control (Figs. 3b and 4). Residue mixtures increased SOM and N in most cases, with the exception of the effect of the strawcompost treatment on SOM. Nonetheless, there was a nonadditive effect in SOM and $\mathrm{N}$ in the straw-compost treatment as this nonadditivity was in fact a negation of the negative effect on SOM and $\mathrm{N}$ of straw applied as an individual residue.

Treatment effects on SOM or N levels were not significantly different between treatments (SOM $-F=0.981$ and $p=0.456 ; \mathrm{N}-F=1.81$ and $p=0.163$; one-way ANOVA), but the compost factor tended to increase soil $\mathrm{N}$ ( $F=3.88$; $p=0.065$; two-way ANOVA). Soil respiration in the different treatments was rather similar in all treatments, and none of the treatments caused soil respiration to deviate significantly from the control - or from each other $(F=1.358$; $p=0.286$; one-way ANOVA; see S3 in the Supplement).

The addition of compost, either as an individual residue or in a mixture, significantly affected available $\mathrm{K}(F=7.761$; $p=0.012)$ and $\mathrm{Mg}(F=4.953 ; p=0.039$; Fig. 5a). Akin to soil $\mathrm{N}$ and SOM, the lowest levels of nutrients were found in soils amended with the straw-only treatment. The increases in nutrient availability were not consistent with the crop residue amendments and ranged from $-242 \%$ to $57 \%$ of the nutrients added as part of the amendments (see S4 in the Supplement). If there was an increase in nutrients, the contribution of the amendments was relatively small in most cases and exhibited very large error margins. The most notable observations from these data are the consistent immobilisation of nutrients brought about by the straw-only treatment, 


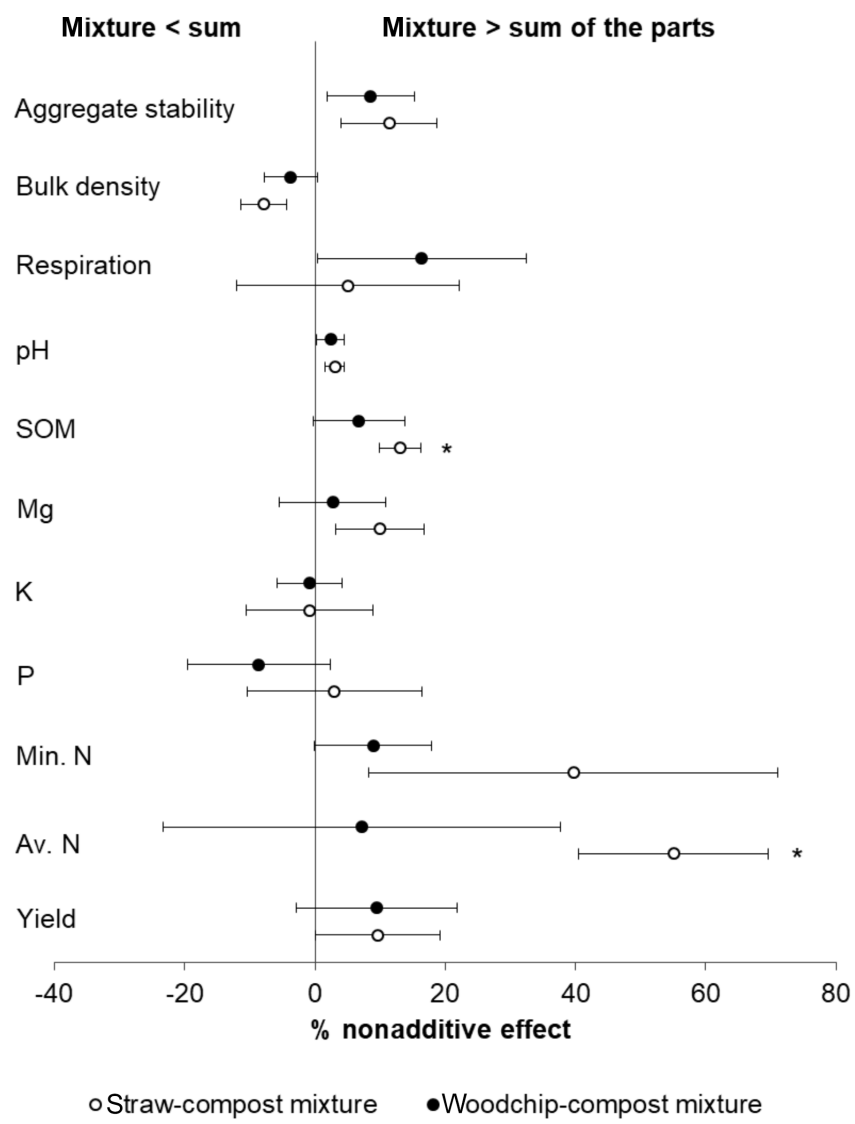

Figure 2. Nonadditive effects of crop residue mixtures on soil properties. The percent of the nonadditive effect is the difference in the percent effect between the mixture and the sum of the parts. Positive percent nonadditive effects mean that the effect of the mixture is greater than the sum of the parts and vice versa. Yield is the total lettuce biomass produced per plot; Av. $\mathrm{N}$ is the available N; Min. $\mathrm{N}$ is potentially mineralisable $\mathrm{N}$; soil $\mathrm{P}, \mathrm{K}$, and $\mathrm{Mg}$ are available nutrients; SOM is measured as a loss on ignition (LOI); and soil respiration is assessed by $\mathrm{CO}_{2}$ burst. Error bars represent standard error of the mean (SEM; $n=4)$. Significant difference from zero (where $0=$ no significant nonadditivity) is indicated by * (one-tailed $T$ test; $p<0.05)$

while amendments including woodchips or compost had a tendency to modestly increase available nutrients. None of the nutrient increases exceeded $100 \%$ of the nutrients added, indicating that residue amendments did not result in the net mobilisation or mineralisation of nutrients already present in the soil.

We observed no significant effects on the aggregate stability of the differently amended soils, but the soil bulk density tended to be lowered by the residue factor, i.e. when a low-quality residue was part of the treatment $(F=3.28$; $p=0.062$; two-way ANOVA; Fig. 5b).
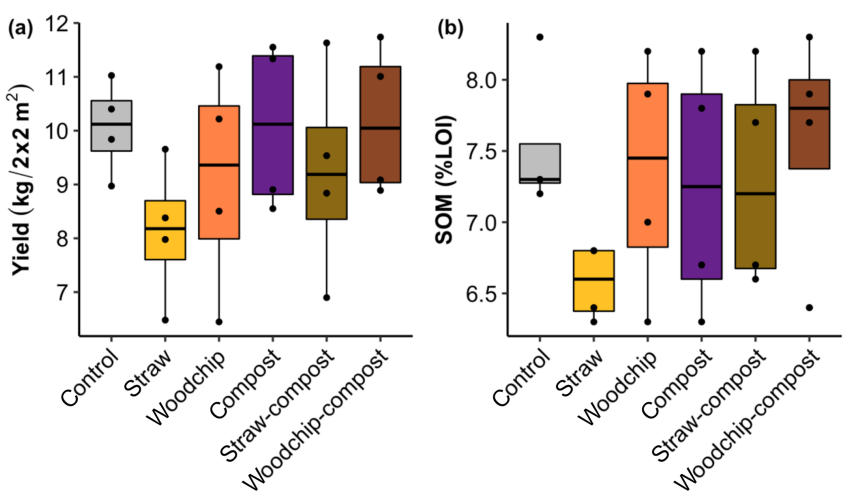

Figure 3. (a) Gem lettuce yield as total biomass produced per $2 \mathrm{~m} \times$ $2 \mathrm{~m}$ plot sampled. (b) Soil organic matter by percent loss on ignition (\% LOI) after each soil amendment treatment. Lower and upper hinges correspond to the 25th and 75th percentiles; black dots represent individual data points, which occasionally overlap $(n=4)$.

Potentially mineralisable $\mathrm{N}$ 日 Available $\mathrm{N}$

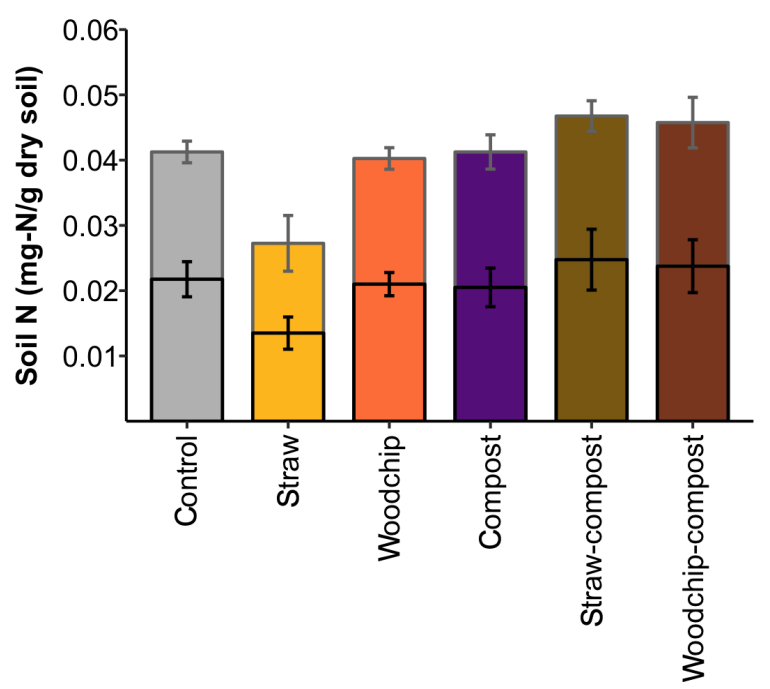

Figure 4. Available and potentially mineralisable $\mathrm{N}$ after each soil amendment treatment. Error bars represent the SEM of available and potentially mineralisable $\mathrm{N}$ separately $(n=4)$.

\subsection{Correlations}

A number of noteworthy correlations may help to explain the data and are summarised in Table 5. There were some significant correlations between the number of nutrients applied and the amount of available $\mathrm{K}$ and $\mathrm{Mg}$ in the soils at the end of the experiment, which indicates a positive effect of the residue amendments. The amount of $\mathrm{C}$ applied via the residue amendments was not correlated with the levels of SOM. The yield was positively and significantly correlated with the sum of available and potentially mineralisable $\mathrm{N}$, available $\mathrm{P}$ and $\mathrm{Mg}$, SOM, and aggregate stability. SOM was also positively correlated with available $\mathrm{N}, \mathrm{P}$, and $\mathrm{Mg}$, and with soil respiration. 


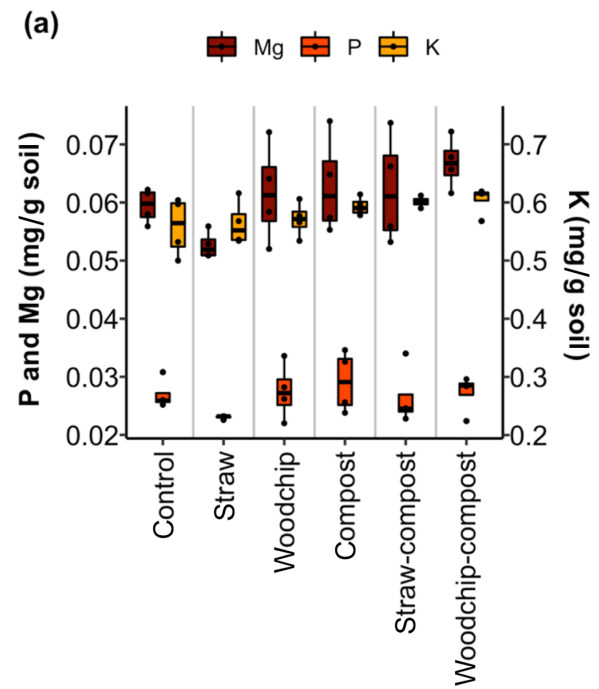

(b) Bulk density 审 Aggregate stability

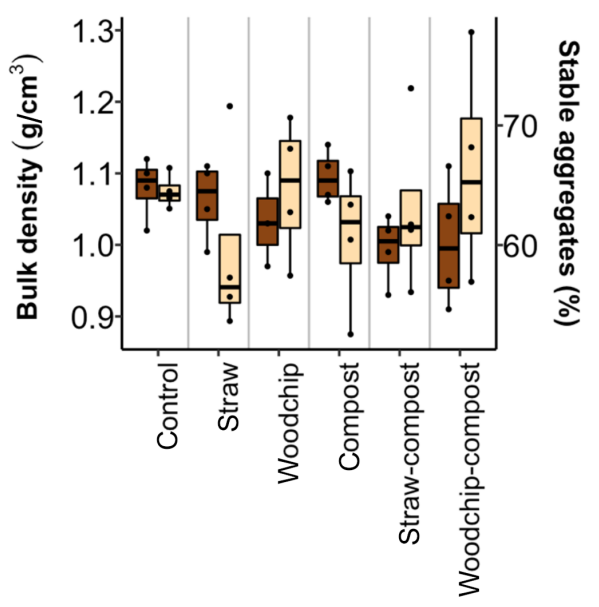

Figure 5. (a) Available nutrients after each soil amendment treatment. (b) Soil physical properties after each treatment. Lower and upper hinges correspond to the 25th and 75th percentiles; black dots represent individual data points, which occasionally overlap $(n=4)$.

Table 5. Selected Pearson correlations ( $r$ values). Significance indicated as ${ }^{* *} p<0.05$ and ${ }^{*} p<0.10$.

\begin{tabular}{lllllllll}
\hline & Yield & Av. N & Av. and Min. N & P & K & Mg & SOM & Resp. \\
\hline App_C & -0.10 & 0.17 & 0.17 & -0.07 & $0.40^{*}$ & 0.22 & 0.00 & -0.01 \\
App_N & 0.07 & 0.26 & 0.30 & 0.08 & $0.54^{* *}$ & 0.32 & 0.06 & -0.09 \\
App_P & $0.00^{*}$ & 0.20 & $0.23^{*}$ & 0.00 & $0.49^{* *}$ & $0.22^{*}$ & -0.01 & -0.17 \\
App_K & 0.17 & 0.30 & 0.36 & 0.17 & $0.56^{* *}$ & 0.39 & 0.12 & -0.05 \\
App_Mg & 0.19 & 0.33 & $0.38^{*}$ & 0.19 & $0.56^{* *}$ & $0.45^{* *}$ & 0.16 & 0.02 \\
Yield & - & 0.29 & $0.45^{* *}$ & $0.75^{* *}$ & 0.19 & $0.78^{* *}$ & $0.74^{* *}$ & $0.36^{*}$ \\
Av. N & 0.29 & - & $0.91^{* *}$ & $0.42^{* *}$ & 0.27 & $0.55^{* *}$ & $0.58^{* *}$ & $0.36^{*}$ \\
Av. and Min. N & $0.45^{* *}$ & $0.91^{* *}$ & - & $0.49^{* *}$ & $0.35^{*}$ & $0.61^{* *}$ & $0.65^{* *}$ & 0.30 \\
P & $0.75^{* *}$ & $0.42^{* *}$ & $0.49^{* *}$ & - & 0.02 & $0.83^{* *}$ & $0.86^{* *}$ & $0.51^{* *}$ \\
K & 0.19 & 0.27 & $0.35^{*}$ & 0.02 & - & $0.35^{*}$ & 0.02 & -0.26 \\
Mg & $0.78^{* *}$ & $0.55^{* *}$ & $0.61^{* *}$ & $0.83^{* *}$ & $0.35^{*}$ & - & $0.80^{* *}$ & $0.47^{* *}$ \\
SOM & $0.74^{* *}$ & $0.58^{* *}$ & $0.65^{* *}$ & $0.86^{* *}$ & 0.02 & $0.80^{* *}$ & - & $0.62^{* *}$ \\
Agg. stab. & $0.45^{* *}$ & $0.55^{* *}$ & $0.48^{* *}$ & $0.36^{*}$ & $0.00^{*}$ & $0.58^{* *}$ & $0.58^{* *}$ & $0.41^{* *}$ \\
Overall qual. & 0.20 & $0.51^{* *}$ & $0.46^{* *}$ & 0.10 & 0.34 & 0.23 & 0.21 & 0.14 \\
\hline
\end{tabular}

Abbreviations: App_ - application rate of; Av. - available; Min. - potentially mineralisable; Agg. stab. - aggregate stability. Resp. - soil respiration; and Overall qual. - overall quality impairment.

\section{Discussion}

\subsection{Nonadditive effects}

The objective of this study was to find out if greater benefits could be obtained from crop residue soil amendments in an arable soil by applying them as chemically heterogeneous mixtures of low $\mathrm{C}: \mathrm{N}$ vegetable waste compost and high $\mathrm{C}: \mathrm{N}$ straw or woodchips, compared to individual residue amendments. Relative benefits of the mixtures were assessed by calculating the nonadditivity of a range of effects, including yield and a selection of soil properties that are likely to be beneficial for crop production. We found some degree of nonadditivity in the direction (synergy or antagonism) we predicted in most parameters (except available $\mathrm{P}$ in the woodchip-compost mixture and available $\mathrm{K}$ in both mixtures) and significant nonadditive increases in available $\mathrm{N}$ and SOM after application of the straw-compost mixture, indicating that even after a short amount of time (44d) the beneficial effects from a mixture of residues can be greater than the sum of their parts.

Examining per-treatment effects can help further explain the nonadditivity results. The per-treatment difference in terms of SOM and available $\mathrm{N}$ between the woodchipcompost treatment and the straw-compost treatment was relatively small. Yet, only the straw-compost mixture exhibited significant nonadditivity. Comparison of the per-treatment effects on SOM and available $\mathrm{N}$ reveals that the significant nonadditive effects observed after application of the straw- 
compost mixture are in fact a negation of the negative (compared to control) effect of the straw-only treatment. As suggested earlier, this indicates that the decomposition of single crop residue amendments does not always translate into agronomic benefits, and applying mixtures of crop residues could be a route to improving those benefits.

\subsection{Decomposition}

Although we suggested that nonadditive effects might be related to differences in decomposition rates in the mixtures, compared to the individual residues, we have no evidence of this in terms of soil respiration measurements. At the time of sampling, high microbial activity may have increased $\mathrm{N}$ immobilisation and therefore decreased soil mineral $\mathrm{N}$ availability. However, respiration rates were equally low in the straw-only ( $\mathrm{N}$ immobilisation) and the strawcompost treatments ( $\mathrm{N}$ mineralisation), and both were lower than the control (see S3 in the Supplement). Likewise, Redin et al. (2014), who studied residue mixtures of stems and leaves of 25 different arable crop species, found mostly additive effects for decomposition rates of mixtures, but, unlike the results presented here, they found no synergistic effects on $\mathrm{N}$ mineralisation. Both here and in the study by Redin et al. (2014) decomposition was measured in terms of $\mathrm{C}$ mineralisation (measured as $\mathrm{CO}_{2}$ release), which does not account for the possibility of a higher CUE when chemically diverse residue mixtures are applied and also does not distinguish between the mineralisation of residues or organic matter already present in the soil. Moreover, our soil respiration measurements were taken by the Solvita burst method on soil samples removed from the field and sieved to $2 \mathrm{~mm}$, removing parts of residues and other organic matter greater than $2 \mathrm{~mm}$, which may not have been a good representation of the respiration produced in situ by a soil mixed with crop residues at various stages of decomposition.

Another reason for the absence of different soil respiration rates may be the relatively short duration of this experiment, which covered the short growing period of gem lettuce. As pointed out by Lecerf et al. (2011), niche complementarity effects, in which different groups of decomposing organisms (already present in the soil or newly introduced via the residues) develop a synergistic association in residue breakdown, tend to advance with time, leading to a generally higher number of long-term, litter-mixing studies finding nonadditive effects. Indeed, Ball et al. (2014) only observed a nonadditive effect on mass loss in a five-component mixture after $193 \mathrm{~d}$. Therefore an experiment of a longer duration may be able to capture more and greater treatment effects and nonadditive effects.

\subsection{Yield}

Although the yield, assessed by the total biomass of gem lettuce produced per plot, was not significantly affected by any of the treatments or factors, there were some notable differences between treatments. The yield appeared to be somewhat depressed by the straw-only treatment, which is not surprising considering the lower concentration of available $\mathrm{N}$, SOM, soil nutrients, and aggregate stability in this treatment compared to the control. Crops tend to require the most nitrogen during the vegetative growth stage, and when this is not available, the yield will be affected (Chen et al., 2014). The lettuce plants were planted as plugs just after the application of the treatments, so when they were introduced to the experimental plots they were already in their vegetative stage. Significant positive correlations of the yield with the sum of available and potentially mineralisable $\mathrm{N}$, available $\mathrm{P}$ and $\mathrm{Mg}$, SOM, and aggregate stability suggest that these are the main benefits provided by the crop residue amendments from an agronomic perspective.

Overall symptoms of poor lettuce quality were observed least in the straw-only treatments, despite the location of these treatments being towards the low soil $\mathrm{C}$ end of the field site (see $\mathrm{S} 1$ in the Supplement). Available $\mathrm{N}$ levels were positively correlated with overall quality impairment (i.e. percent of lettuce heads affected by some form of quality impairment; $p=0.011)$, and in particular with yellow tips $(p=0.017)$ and tip burn $(p=0.041)$, which may indicate that the crop was suffering from $\mathrm{N}$ deficiency (Table 5). Indeed, the $\mathrm{N}$ levels were relatively low compared to those recommended for lettuce crops (RB209, 2019), and N deficiency leads to reduced plant size, which would lead to decreased biomass production and chlorosis and outside leaves senescing prematurely and dropping off (Brady and Weil, 2002), all of which were observed.

\subsection{Nutrient dynamics and transfer}

The straw-only treatment led to a notable immobilisation of $\mathrm{N}$, which was unlike the other treatments. Although this could be only a temporary effect (e.g. as in Silgram and Chambers, 2002), it may be unfavourable for lettuce crop productivity and should be taken into account when timing crop residue applications. The notable $\mathrm{N}$ immobilisation in the straw-only treatment suggests that straw decomposed differently as an individual residue than in a mixture with compost, which could be explained by the $\mathrm{C}: \mathrm{N}$ ratio of the treatments. Chen et al. (2014) evaluated soil N processing during crop residue decomposition and suggested that residues with a $\mathrm{C}: \mathrm{N}$ ratio below $\sim 25$ result in net mineralisation (an increase in available $\mathrm{N}$ ), and those with a $\mathrm{C}: \mathrm{N}$ ratio above $\sim 30$ result in net immobilisation (a decrease in available $\mathrm{N}$ ). Therefore, in the present study the woodchip-only $(\mathrm{C}: \mathrm{N}=64)$ and straw-only $(\mathrm{C}: \mathrm{N}=41)$ treatments are both expected to result in net $\mathrm{N}$ immobilisation. The reason why 
$\mathrm{N}$ immobilisation was only observed in the straw treatment could be due to a lower decomposition rate of the woodchips and, therefore, a lower microbial $\mathrm{N}$-mining requirement at the time of sampling. Straw is likely more decomposable due to a comparatively lower $\mathrm{C}: \mathrm{N}$ ratio, a higher water-holding capacity (being more friable and having a greater surface area to hold on to moisture; Hättenschwiler et al., 2005; Iqbal et al., 2015), and possibly a soil microbial community that is more adapted to decomposing straw because wheat is sometimes grown in these soils.

A slight increase in soil $\mathrm{N}$ (available and potentially mineralisable $\mathrm{N}$ ) observed in the straw-compost treatment, and to a lesser extent in the woodchip-compost treatment, compared to the control could be due to $\mathrm{N}$ derived from the compost, the residue, or the primed native SOM. Priming of native SOM caused by the amendment seems unlikely in the woodchip-compost treatment because SOM levels were higher compared to the control treatment. Even in the strawcompost treatment, the SOM level was very close to that of the control treatment, suggesting that the net mineralisation of native SOM as a result of the residue amendment was negligible. Compost was the most significant factor related to higher soil $\mathrm{N}$ levels, which can be attributed to its low $\mathrm{C}: \mathrm{N}$ ratio, allowing for easy decomposition with minimal immobilisation of native soil mineral $\mathrm{N}$. In the residue mixtures, it is likely that compost provided nutrients for decomposer microbes to be able to decompose the high $\mathrm{C}: \mathrm{N}$ residues (i.e. interspecific nutrient transfer).

Therefore, the nonadditive effects on soil $\mathrm{N}$ in the strawcompost treatment can probably be attributed to interspecific net transfer of $\mathrm{N}$ from high $\mathrm{N}$ to low $\mathrm{N}$ residues, resulting in (1) the retention of compost-derived $\mathrm{N}$ by straw or woodchips in the mixture, preventing it from being leached, and (2) a higher nutrient availability in treatments including compost, enabling decomposer organisms to break down and release the $\mathrm{N}$ contained in the amendment mixture more readily. The transfer of $\mathrm{N}$ can occur by a combination of the uptake and release by microbes on the high $\mathrm{N}$ residue as they produce enzymes for decomposition and diffusion along a gradient of high $\mathrm{N}$ to low $\mathrm{N}$ (Schimel and Hättenschwiler, 2007). The woodchips likely had a higher lignin content than the straw. Ligninolytic enzyme production can be inhibited by elevated $\mathrm{N}$ concentrations (Carreiro et al., 2000; Knorr et al., 2005), resulting in a relatively greater inhibition of decomposition of the woodchips.

The transfer of $\mathrm{N}$ in litter mixtures appears to go hand in hand with $\mathrm{C}$ transfer. In a microcosm experiment by Berglund et al. (2013) on pine and maize litters inoculated with both forest and arable soils, mixing residues mostly increased the $\mathrm{C}$ loss from the lower quality litter, while the $\mathrm{C}$ released from the higher quality litter was equivalent to decomposing as an individual litter. Therefore, the nonadditively higher SOM in the straw-compost treatment is likely to be the result of enhanced $\mathrm{C}$ release from the straw due to the addition of compost. This phenomenon could be ex- plained by a bidirectional transfer of $\mathrm{C}$ and $\mathrm{N}$ between highand low-quality residues - e.g. via transport of amino acids by fungal mycelia (Tlalka et al., 2007) - where increased $\mathrm{N}$ availability near the low-quality residue enhances its decomposition and subsequent $C$ release, while increased $C$ in the presence of the high-quality residue has little effect on its decomposition (Berglund et al., 2013).

\subsection{Soil physical structure}

Increased SOM positively affects aggregate stability because soil microbes feeding on organic substrates enhance soil aggregate formation and stability by biofilm formation and the production of extracellular polymeric substances that increase cohesion between soil particles (Martens, 2000; Totsche et al., 2018). Aggregate stability, in turn, is involved in the protection of mineral-associated SOM (Angst et al., 2017). Therefore, with an increase in SOM an increase in aggregate stability would be expected, and we did indeed observe a positive correlation between these variables $(p=0.028)$. We also observed a positive correlation between aggregate stability and available $\mathrm{N}(p=0.005)$. This is contrary to the observation that high-quality residues and/or the addition of $\mathrm{N}$ fertilisers result in higher aggregate turnover (formation and breakdown) compared to a greater aggregate stability when low-quality residues are applied (Chivenge et al., 2011).

Because we observed positive effects on both soil $\mathrm{N}$ and SOM from crop residue mixtures, an increased nonadditive effect on the soil physical structure from application of the right residue mixtures can therefore be anticipated over time. However, in many arable cropping systems tillage may undermine the emergence of this benefit by destroying soil aggregates and exposing the SOM contained within (Nath and Lal, 2017). Furthermore, bulk density was lowered by the addition of the low-quality residues (straw and woodchips; $p=0.062$ ), especially when combined with compost. This could be partially due to increases in the aggregate stability in most of these treatments, although some residues (with a lower density than soil) may have also been included in the bulk density ring when sampling.

\subsection{Potential of residue mixing to obtain more benefits from low-quality residues}

Our study provides some evidence that chemically heterogeneous crop residue mixtures can provide agronomically beneficial nonadditive effects. We found the prevention of $\mathrm{N}$ immobilisation to be the most prominent effect in the short term. Positive nonadditivity in SOM levels and other soil nutrients may develop over time, but a longer term experiment is necessary to investigate this.

Other authors have also found beneficial effects on soil $\mathrm{N}$ levels from mixed residue amendments. For instance, Kaewpradit et al. (2009) mixed groundnut residues (high N) and 
rice straw (low $\mathrm{N}$ ), which slowed down $\mathrm{N}$ loss by mineralisation during the phase between two different crops, i.e. a beneficial temporary N immobilisation. McDaniel et al. (2016) found that nonadditive effects of soil $\mathrm{C}$ and $\mathrm{N}$ dynamics after the application of residue mixtures depend on the diversity in cropping history, with nonadditive effects primarily observed in monoculture soils rather than diverse crop rotations. The authors attribute this to the low respiration rates from monoculture soils after the application of low-quality residues, while soil response to high-quality residues is similar in both monoculture and crop rotation soils (McDaniel et al., 2016). These studies indicate that potential benefits from residue mixing are dependent on the arable cropping system.

Manipulation of the number of component residues, the mixing ratio, and the quantity applied can be used to optimise the timing and the amount of nutrient release for a better synchrony with crop demand (Myers et al., 1997). For instance, Kuo and Sainju (1998) demonstrated that the timing of N mineralisation can be manipulated by the proportion of leguminous cover crop residues in the mixture, while Mao and Zeng (2012) found that both the number of residue components and their mixing ratio affected nonadditivity. Furthermore, the quantity of residues applied can impact on microbial CUE; while microbial CUE is often unaffected at low substrate additions, applications of high amounts of the same material can lead to diminishing CUE levels (Jones et al., 2018), e.g., as shown by Roberts et al. (2007), with glucose and glucosamine additions to various foraging soil types in a microcosm experiment.

The interplay of environmental factors and amendment properties affect microbial CUE and the mechanisms involved in the nonadditivity of decomposing residue mixtures on soil properties (Kuebbing and Bradford, 2019); these need to be accounted for in order to create a methodology for optimised benefits from crop residues as soil amendments in arable cropping systems. Therefore, future research on residue mixtures should incorporate not only substrate quality but also the application rate (quantity), diversity (number of residue species), and mixing ratio and how these interact with different arable soil types.

\section{Conclusions}

This experiment tested the agronomic benefits obtained from multicomponent and chemically heterogeneous residue mixtures compared to the individual residues. Significant positive nonadditive effects on available $\mathrm{N}$ and SOM were measured after the application of a straw-compost mixture, so we can partially accept our first hypothesis that predicted greater levels of available nutrients and SOM in mixtures compared to individual residues. However, due to variation in the total percent of $\mathrm{C}$ contents across the experimental field site, we have some reservations about this result. Nevertheless, this study provides some evidence for the potential of crop residue mixtures to provide greater agronomic benefits than single high-C residue amendments of straw or woodchips, at least in terms of preventing $\mathrm{N}$ immobilisation during crop growth.

Data availability. Data have been uploaded to Mendeley Data, https://doi.org/10.17632/jcrvmb8hwy.2 (Struijk et al., 2020).

Supplement. The supplement related to this article is available online at: https://doi.org/10.5194/soil-6-467-2020-supplement.

Author contributions. MS and TS designed the experiment and performed the field work. MS carried out the laboratory work. MS analysed the data, with support from TS and APW. MS prepared the paper, with critical reviews by all authors. TS secured funding and established contact with the farm where the experiment was carried out. TS supervised the project and APW and SRM co-supervised the project.

Competing interests. The authors declare that they have no conflict of interest.

Acknowledgements. This work was funded by a University of Reading Faculty of Science and School of Archaeology, Geography and Environmental Science (SAGES) studentship awarded to Marijke Struijk. Research expenses were provided by the Waitrose Agronomy Group. Andrew P. Whitmore acknowledges support from the Biotechnology and Biological Sciences Research Council (BBSRC)-funded Soil to Nutrition programme (grant no. BBS/E/C/000I0330). We thank G's Growers Ltd and their employees for the supply of materials and access to the field site, Xin Shu and Adetunji Adekanmbi for help in the field, Omar ElHuni and Alfonso Rodriguez Vila for help with the laboratory work, and Anne S. Dudley, Karen J. Gutteridge, Ilse Kamerling, Fengjuan Xiao and Chris Speed for technical assistance in the laboratory.

Financial support. This research has been supported by the Waitrose Agronomy Group, the University of Reading Faculty of Science/SAGES Studentship, and the Biotechnology and Biological Sciences Research Council (BBSRC)-funded Soil to Nutrition programme (grant no. 75 BBS/E/C/000I0330).

Review statement. This paper was edited by Claudio Zaccone and reviewed by Flavia Pinzari and one anonymous referee. 


\section{References}

Allison, S. D., Wallenstein, M. D., and Bradford, M. A.: Soil-carbon response to warming dependent on microbial physiology, Nat. Geosci., 3, 336-340, https://doi.org/10.1038/ngeo846, 2010.

Aneja, M. K., Sharma, S., Fleischmann, F., Stich, S., Heller, W., Bahnweg, G., Munch, J. C., and Schloter, M.: Microbial colonization of beech and spruce litter - Influence of decomposition site and plant litter species on the diversity of microbial community, Microb. Ecol., 52, 127-135, https://doi.org/10.1007/s00248-006-9006-3, 2006.

Angst, G., Mueller, K. E., Kögel-Knabner, I., Freeman, K. H., and Mueller, C. W.: Aggregation controls the stability of lignin and lipids in clay-sized particulate and mineral associated organic matter, Biogeochemistry, 132, 307-324, https://doi.org/10.1007/s10533-017-0304-2, 2017.

Bailey, V., Smith, J., and Bolton, H.: Fungal-to-bacterial ratios in soils investigated for enhanced $\mathrm{C}$ sequestration, Soil Biol. Biochem., 34, 997-1007, https://doi.org/10.1016/S00380717(02)00033-0, 2002.

Ball, B. A., Carrillo, Y., and Molina, M.: The influence of litter composition across the litter-soil interface on mass loss, nitrogen dynamics and the decomposer community, Soil Biol. Biochem., 69, 71-82, https://doi.org/10.1016/J.SOILBIO.2013.10.048, 2014.

Bastian, F., Bouziri, L., Nicolardot, B., and Ranjard, L.: Impact of wheat straw decomposition on successional patterns of soil microbial community structure, Soil Biol. Biochem., 41, 262-275, https://doi.org/10.1016/j.soilbio.2008.10.024, 2009.

Berglund, S. L., Ågren, G. I., and Ekblad, A.: Carbon and nitrogen transfer in leaf litter mixtures, Soil Biol. Biochem., 57, 341-348, https://doi.org/10.1016/J.SOILBIO.2012.09.015, 2013.

Brady, N. C. and Weil, R. R.: The Nature and Properties of Soils, 13th Edn., Prentice Hall, Upper Saddle River, New Jersey, 544 pp., 2002.

Briones, M. J. I. and Ineson, P.: Decomposition of eucalyptus leaves in litter mixtures, Soil Biol. Biochem., 28, 1381-1388, https://doi.org/10.1016/S0038-0717(96)00158-7, 1996.

Carreiro, M. M., Sinsabaugh, R. L., Repert, D. A., and Parkhurst, D. F.: Microbial enzyme shifts explain litter decay responses to simulated nitrogen deposition, Ecology, 81, 2359-2365, https://doi.org/10.1890/00129658(2000)081[2359:MESELD]2.0.CO;2, 2000.

Catt, J. A., Howse, K. R., Christian, D. G., Lane, P. W., Harris, G. L., and Goss, M. J.: Strategies to decrease nitrate leaching in the Brimstone Farm Experiment, Oxfordshire, UK, 1988-93: the effect of straw incorporation, J. Agric. Sci., 131, 309-320, https://doi.org/10.1017/S0021859698005905, 1998.

Chen, B., Liu, E., Tian, Q., Yan, C., and Zhang, Y.: Soil nitrogen dynamics and crop residues. A review, Agron. Sustain. Dev., 34, 429-442, https://doi.org/10.1007/s13593-014-0207-8, 2014.

Chivenge, P., Vanlauwe, B., Gentile, R., and Six, J.: Organic resource quality influences short-term aggregate dynamics and soil organic carbon and nitrogen accumulation, Soil Biol. Biochem., 43, 657-666, https://doi.org/10.1016/J.SOILBIO.2010.12.002, 2011.

Cong, W.-F., van Ruijven, J., Mommer, L., De Deyn, G. B., Berendse, F., and Hoffland, E.: Plant species richness promotes soil carbon and nitrogen stocks in grasslands without legumes, edited by: Lavorel, S., J. Ecol., 102, 1163-1170, https://doi.org/10.1111/1365-2745.12280, 2014.

Cosentino, D., Chenu, C., and Le Bissonnais, Y.: Aggregate stability and microbial community dynamics under drying-wetting cycles in a silt loam soil, Soil Biol. Biochem., 38, 2053-2062, https://doi.org/10.1016/J.SOILBIO.2005.12.022, 2006.

Cotrufo, M. F., Soong, J. L., Horton, A. J., Campbell, E. E., Haddix, M. L. L., Wall, D. H., and Parton, W. J.: Formation of soil organic matter via biochemical and physical pathways of litter mass loss, Nat. Geosci., 8 available at: http://www.nature.com/ articles/ngeo2520 (last access: 17 October 2019), 2015.

Eisenhauer, N., Dobies, T., Cesarz, S., Hobbie, S. E., Meyer, R. J., Worm, K., and Reich, P. B.: Plant diversity effects on soil food webs are stronger than those of elevated $\mathrm{CO}_{2}$ and $\mathrm{N}$ deposition in a long-term grassland experiment, P. Natl. Acad. Sci. USA, 110, 6889-94, https://doi.org/10.1073/pnas.1217382110, 2013.

Fierer, N., Lauber, C. L., Ramirez, K. S., Zaneveld, J., Bradford, M. A., and Knight, R.: Comparative metagenomic, phylogenetic and physiological analyses of soil microbial communities across nitrogen gradients, ISME J., 6, 1007-1017, https://doi.org/10.1038/ismej.2011.159, 2012.

Garnier, E. and Navas, M.-L.: A trait-based approach to comparative functional plant ecology: concepts, methods and applications for agroecology, A review, Agron. Sustain. Dev., 32, 365-399, https://doi.org/10.1007/s13593-011-0036-y, 2012.

Gartner, T. B. and Cardon, Z. G.: Decomposition dynamics in mixed-species leaf litter, Oikos, 104, 230-246, https://doi.org/10.1111/j.0030-1299.2004.12738.x, 2004.

Gurr, G. M., Wratten, S. D., and Luna, J. M.: Multi-function agricultural biodiversity: pest management and other benefits, Basic Appl. Ecol., 4, 107-116, https://doi.org/10.1078/1439-179100122, 2003.

Hättenschwiler, S., Tiunov, A., and Scheu, S.: Biodiversity and litter decomposition in terrestrial ecosystems, Annu. Rev. Ecol. Evol., 36, 191-218, https://doi.org/10.1146/annurev.ecolsys.36.112904.151932, 2005.

Ho, A., Di Lonardo, D. P., and Bodelier, P. L. E.: Revisiting life strategy concepts in environmental microbial ecology, FEMS Microbiol. Ecol., 93, fix006, https://doi.org/10.1093/femsec/fix006, 2017.

Iqbal, A., Aslam, S., Alavoine, G., Benoit, P., Garnier, P., and Recous, S.: Rain regime and soil type affect the $\mathrm{C}$ and $\mathrm{N}$ dynamics in soil columns that are covered with mixed-species mulches, Plant Soil, 393, 319-334, https://doi.org/10.1007/s11104-0152501-x, 2015.

Jones, D. L., Hill, P. W., Smith, A. R., Farrell, M., Ge, T., Banning, N. C., and Murphy, D. V.: Role of substrate supply on microbial carbon use efficiency and its role in interpreting soil microbial community-level physiological profiles (CLPP), Soil Biol. Biochem., 123, 1-6, https://doi.org/10.1016/j.soilbio.2018.04.014, 2018.

Kaewpradit, W., Toomsan, B., Cadisch, G., Vityakon, P., Limpinuntana, V., Saenjan, P., Jogloy, S., and Patanothai, A.: Mixing groundnut residues and rice straw to improve rice yield and $\mathrm{N}$ use efficiency, F. Crop. Res., 110, 130-138, https://doi.org/10.1016/J.FCR.2008.07.011, 2009.

Kallenbach, C. M., Wallenstein, M. D., Schipanksi, M. E., and Grandy, A. S.: Managing agroecosystems for soil mi- 
crobial carbon use efficiency: ecological unknowns, potential outcomes, and a path forward, Front. Microbiol., 10, 1146, https://doi.org/10.3389/fmicb.2019.01146, 2019.

Knorr, M., Frey, S. D., and Curtis, P. S.: Nitrogen additions and litter decomposition: A meta-analysis, Ecology, 86, 3252-3257, https://doi.org/10.1890/05-0150, 2005.

Kuebbing, S. E. and Bradford, M. A.: The potential for mass ratio and trait divergence effects to explain idiosyncratic impacts of non-native invasive plants on carbon mineralization of decomposing leaf litter, edited by: Morriën, E., Funct. Ecol., 33, 13652435, https://doi.org/10.1111/1365-2435.13316, 2019.

Kumar, K. and Goh, K. M.: Crop residues and management practices: effects on soil quality, soil nitrogen dynamics, crop yield, and nitrogen recovery, Adv. Agron., 68, 197-319, https://doi.org/10.1016/S0065-2113(08)60846-9, 1999.

Kuo, S. and Sainju, U. M.: Nitrogen mineralization and availability of mixed leguminous and non-leguminous cover crop residues in soil, Biol. Fertil. Soils, 26, 346-353, https://doi.org/10.1007/s003740050387, 1998.

Lange, M., Eisenhauer, N., Sierra, C. A., Bessler, H., Engels, C., Griffiths, R. I., Mellado-Vázquez, P. G., Malik, A. A., Roy, J., Scheu, S., Steinbeiss, S., Thomson, B. C., Trumbore, S. E., and Gleixner, G.: Plant diversity increases soil microbial activity and soil carbon storage, Nat. Commun., 6, 6707, https://doi.org/10.1038/ncomms7707, 2015.

Lecerf, A., Marie, G., Kominoski, J. S., LeRoy, C. J., Bernadet, C., and Swan, C. M.: Incubation time, functional litter diversity, and habitat characteristics predict litter-mixing effects on decomposition, Ecology, 92, 160-169, https://doi.org/10.1890/10-0315.1, 2011.

Li, X.-M., Chen, Q.-L., He, C., Shi, Q., Chen, S.-C., Reid, B. J., Zhu, Y.-G., and Sun, G.-X.: Organic carbon amendments affect the chemodiversity of soil dissolved organic matter and its associations with soil microbial communities, Environ. Sci. Technol., 53, 50-59, https://doi.org/10.1021/acs.est.8b04673, 2019.

Ludwig, M., Achtenhagen, J., Miltner, A., Eckhardt, K.-U., Leinweber, P., Emmerling, C., and Thiele-Bruhn, S.: Microbial contribution to SOM quantity and quality in density fractions of temperate arable soils, Soil Biol. Biochem., 81, 311-322, https://doi.org/10.1016/J.SOILBIO.2014.12.002, 2015.

Makkonen, M., Berg, M. P., van Logtestijn, R. S. P., van Hal, J. R., and Aerts, R.: Do physical plant litter traits explain non-additivity in litter mixtures? A test of the improved microenvironmental conditions theory, Oikos, 122, 987-997, https://doi.org/10.1111/j.1600-0706.2012.20750.x, 2013.

Malézieux, E., Crozat, Y., Dupraz, C., Laurans, M., Makowski, D., Ozier-Lafontaine, H., Rapidel, B., Tourdonnet, S., and ValantinMorison, M.: Mixing plant species in cropping systems: concepts, tools and models. A review, Agron. Sustain. Dev., 29, 4362, https://doi.org/10.1051/agro:2007057, 2009.

Mao, R. and Zeng, D.-H.: Non-additive effects vary with the number of component residues and their mixing proportions during residue mixture decomposition: A microcosm study, Geoderma, 170, 112-117, https://doi.org/10.1016/J.GEODERMA.2011.11.008, 2012.

Martens, D. A.: Plant residue biochemistry regulates soil carbon cycling and carbon sequestration, Soil Biol. Biochem., 32, 361369, https://doi.org/10.1016/S0038-0717(99)00162-5, 2000.
Martin, J. P., Martin, W. P., Page, J. B., Raney, W. A., and de Ment, J. D.: Soil aggregation, Adv. Agron., 7, 1-37, https://doi.org/10.1016/S0065-2113(08)60333-8, 1955.

McDaniel, M. D., Grandy, A. S., Tiemann, L. K., and Weintraub, M. N.: Eleven years of crop diversification alters decomposition dynamics of litter mixtures incubated with soil, Ecosphere, 7, e01426, https://doi.org/10.1002/ecs2.1426, 2016.

Medina, J., Monreal, C., Barea, J. M., Arriagada, C., Borie, F., and Cornejo, P.: Crop residue stabilization and application to agricultural and degraded soils: A review, Waste Manag., 42, 41-54, https://doi.org/10.1016/j.wasman.2015.04.002, 2015.

Myers, R. J. K., van Noordwijk, M., and Vityakon, P.: Synchrony of nutrient relase and plant demand: plant litter quality, soil environment and farmer management options, in: Driven by Nature: Plant Litter Quality and Decomposition, edited by: Cadish, G. and Giller, K. E., 215-229, 1997.

Nath, A. J. and Lal, R.: Effects of tillage practices and land use management on soil aggregates and soil organic carbon in the north appalachian region, USA, Pedosphere, 27, 172-176, https://doi.org/10.1016/S1002-0160(17)60301-1, 2017.

Nilsson, M.-C., Wardle, D. A., and DeLuca, T. H.: Belowground and aboveground consequences of interactions between live plant species mixtures and dead organic substrate mixtures, Oikos, 117, 439-449, https://doi.org/10.1111/j.2007.00301299.16265.x, 2008.

Nimmo, J. R. and Perkins, K. S.: Aggregate stability and size distribution, in Methods of soil analysis, Part 4: Physical methods, edited by: Dane, J. H. and Topp, G. C., Soil Science Society of America, Madison, WI, 2002.

Otsing, E., Barantal, S., Anslan, S., Koricheva, J., and Tedersoo, L.: Litter species richness and composition effects on fungal richness and community structure in decomposing foliar and root litter, Soil Biol. Biochem., 125, 328-339, https://doi.org/10.1016/J.SOILBIO.2018.08.006, 2018.

Pérez Harguindeguy, N., Blundo, C. M., Gurvich, D. E., Díaz, S., and Cuevas, E.: More than the sum of its parts? Assessing litter heterogeneity effects on the decomposition of litter mixtures through leaf chemistry, Plant Soil, 303, 151-159, https://doi.org/10.1007/s11104-007-9495-y, 2008.

Powlson, D. S., Glendining, M. J., Coleman, K., and Whitmore, A. P.: Implications for soil properties of removing cereal straw: Results from long-term studies, Agron. J., 103, 279-287, https://doi.org/10.2134/agronj2010.0146s, 2011.

Purahong, W., Wubet, T., Lentendu, G., Schloter, M., Pecyna, M. J., Kapturska, D., Hofrichter, M., Krüger, D., and Buscot, F.: Life in leaf litter: novel insights into community dynamics of bacteria and fungi during litter decomposition, Mol. Ecol., 25, 40594074, https://doi.org/10.1111/mec.13739, 2016.

Quemada, M. and Cabrera, M. L.: Carbon and nitrogen mineralized from leaves and stems of four cover crops, Soil Sci. Soc. Am. J., 59, 471, https://doi.org/10.2136/sssaj1995.03615995005900020029x, 1995.

RB209: Nutrient Management Guide (RB209), Section 6: Vegetable and bulbs, 2019.

Recous, S., Robin, D., Darwis, D., and Mary, B.: Soil inorganic $\mathrm{N}$ availability: Effect on maize residue decomposition, Soil Biol. Biochem., 27, 1529-1538, https://doi.org/10.1016/00380717(95)00096-W, 1995. 
Redin, M., Recous, S., Aita, C., Dietrich, G., Skolaude, A. C., Ludke, W. H., Schmatz, R., and Giacomini, S. J.: How the chemical composition and heterogeneity of crop residue mixtures decomposing at the soil surface affects $\mathrm{C}$ and $\mathrm{N}$ mineralization, Soil Biol. Biochem., 78, 65-75, https://doi.org/10.1016/J.SOILBIO.2014.07.014, 2014.

Roberts, P., Bol, R., and Jones, D. L.: Free amino sugar reactions in soil in relation to soil carbon and nitrogen cycling, Soil Biol. Biochem., 39, 3081-3092, https://doi.org/10.1016/J.SOILBIO.2007.07.001, 2007.

Roller, B. R. and Schmidt, T. M.: The physiology and ecological implications of efficient growth, ISME J., 9, 1481-1487, https://doi.org/10.1038/ismej.2014.235, 2015.

Santonja, M., Foucault, Q., Rancon, A., Gauquelin, T., Fernandez, C., Baldy, V., and Mirleau, P.: Contrasting responses of bacterial and fungal communities to plant litter diversity in a Mediterranean oak forest, Soil Biol. Biochem., 125, 27-36, https://doi.org/10.1016/J.SOILBIO.2018.06.020, 2018.

Schimel, J. P. and Hättenschwiler, S.: Nitrogen transfer between decomposing leaves of different N status, Soil Biol. Biochem., 39, 1428-1436, https://doi.org/10.1016/J.SOILBIO.2006.12.037, 2007.

Schimel, J., Balser, T. C., and Wallenstein, M.: Microbial stressresponse physiology and its implications for ecosystem function, Ecology, 88, 1386-1394, https://doi.org/10.1890/06-0219, 2007.

Seastedt, T. R.: The role of microarthropods in decomposition and mineralization processes, Annu. Rev. Entomol., 29, 25-46, available at: http://www.annualreviews.org/doi/pdf/10.1146/annurev. en.29.010184.000325 (last access: 20 February 2018), 1984.

Silgram, M. and Chambers, B. J.: Effects of long-term straw management and fertilizer nitrogen additions on soil nitrogen supply and crop yields at two sites in eastern England, J. Agric. Sci., 139, 115-127, https://doi.org/10.1017/S0021859602002435, 2002.

Simpson, A. J., Simpson, M. J., Smith, E., and Kelleher, B. P.: Microbially derived inputs to soil organic matter: are current estimates too low?, Environ. Sci. Technol., 41, 8070-8076, https://doi.org/10.1021/es071217x, 2007.
Six, J., Frey, S. D., Thiet, R. K., and Batten, K. M.: Bacterial and fungal contributions to carbon sequestration in agroecosystems, Soil Sci. Soc. Am. J., 70, 555-569, https://doi.org/10.2136/sssaj2004.0347, 2006.

Smil, V.: Crop residues?: Agriculture's largest harvest, Bioscience, 49, 299-308, 1999.

Struijk, M., Whitmore, A., Mortimer, S., and Sizmur, T.: Obtaining more benefits from crop residues as soil amendments by application as chemically heterogeneous mixtures, Mendeley, https://doi.org/10.17632/jcrvmb8hwy.2, 2020.

Thomsen, I. K. and Christensen, B. T.: Yields of wheat and soil carbon and nitrogen contents following long-term incorporation of barley straw and ryegrass catch crops, Soil Use Manag., 20, 432 438, https://doi.org/10.1111/j.1475-2743.2004.tb00393.x, 2006.

Tilman, D., Cassman, K. G., Matson, P. A., Naylor, R., and Polasky, S.: Agricultural sustainability and intensive production practices, Nature, 418, 671-677, https://doi.org/10.1038/nature01014, 2002.

Tlalka, M., Bebber, D. P., Darrah, P. R., Watkinson, S. C., and Fricker, M. D.: Emergence of self-organised oscillatory domains in fungal mycelia, Fungal Genet. Biol., 44, 1085-1095, https://doi.org/10.1016/J.FGB.2007.02.013, 2007.

Totsche, K. U., Amelung, W., Gerzabek, M. H., Guggenberger, G., Klumpp, E., Knief, C., Lehndorff, E., Mikutta, R., Peth, S., Prechtel, A., Ray, N., and Kögel-Knabner, I.: Microaggregates in soils, J. Plant Nutr. Soil Sci., 181, 104-136, https://doi.org/10.1002/jpln.201600451, 2018.

Wardle, D. A., Bonner, K. I., and Nicholson, K. S.: Biodiversity and plant litter: experimental evidence which does not support the view that enhanced species richness improves ecosystem function, Oikos, 79, 247-258, 1997.

$\mathrm{Xu}$, J. M., Tang, C., and Chen, Z. L.: The role of plant residues in $\mathrm{pH}$ change of acid soils differing in initial $\mathrm{pH}$, Soil Biol. Biochem., 38, 709-719, https://doi.org/10.1016/j.soilbio.2005.06.022, 2006. 